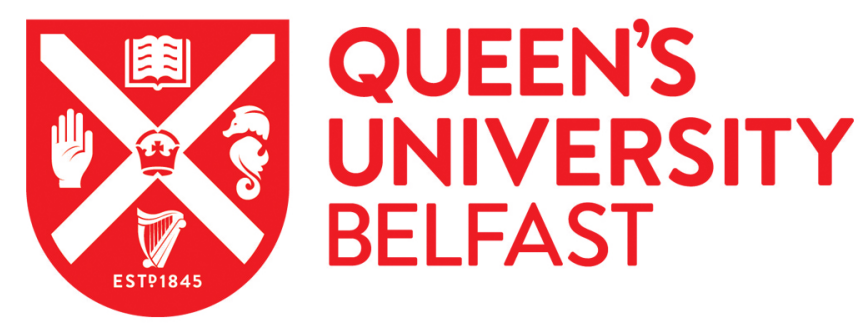

\title{
A review of developments in technologies and research that have had a direct measurable impact on sustainability considering the Paris agreement on climate change
}

Foley, A., Smyth, B. M., Pukšec, T., Markovska, N., \& Duić, N. (2017). A review of developments in technologies and research that have had a direct measurable impact on sustainability considering the Paris agreement on climate change: 10th Conference on Sustainable Development of Energy, Water and Environment Systems (SDEWES) 2015. Renewable and Sustainable Energy Reviews, 68(2), 835-839. https://doi.org/10.1016/j.rser.2016.11.215

Published in:

Renewable and Sustainable Energy Reviews

Document Version:

Peer reviewed version

Queen's University Belfast - Research Portal:

Link to publication record in Queen's University Belfast Research Portal

\footnotetext{
Publisher rights

(C) 2016 Elsevier Ltd. This manuscript version is made available undejavascript:void(0);r the CC-BY-NC-ND 4.0 license

$\mathrm{http}$ ://creativecommons.org/licenses/by-nc-nd/4.0/which permits distribution and reproduction for non-commercial purposes, provided the author and source are cited.
}

\section{General rights}

Copyright for the publications made accessible via the Queen's University Belfast Research Portal is retained by the author(s) and / or other copyright owners and it is a condition of accessing these publications that users recognise and abide by the legal requirements associated with these rights.

\section{Take down policy}

The Research Portal is Queen's institutional repository that provides access to Queen's research output. Every effort has been made to ensure that content in the Research Portal does not infringe any person's rights, or applicable UK laws. If you discover content in the Research Portal that you believe breaches copyright or violates any law, please contact openaccess@qub.ac.uk. 


\title{
A review of developments in technologies and research with a direct measurable impact on sustainability considering the Paris Agreement on Climate Change
}

\author{
Aoife Foley ${ }^{1, *}$, Beatrice M. Smyth ${ }^{1}$, Tomislav Pukšec ${ }^{3}$, Natasa Markovska ${ }^{2}$, Neven Duic ${ }^{3}$ \\ ${ }^{1}$ School of Mechanical \& Aerospace Engineering \\ Queen's University Belfast \\ Ashby Building, Stranmillis Road \\ Belfast BT9 5AH, United Kingdom \\ E-mail address: a.foley@qub.ac.uk \\ ${ }^{2}$ Research Center for Energy and Sustainable Development, \\ Macedonian Academy of Sciences and Arts (ICEOR-MASA), \\ P.O. Box 428, Skopje, Macedonia \\ ${ }^{3}$ Department of Energy, Power Engineering and Environment, \\ University of Zagreb, Faculty of Mechanical Engineering and Naval \\ Architecture, Ivana Lučića 5, 10002 Zagreb, Croatia \\ $*=$ corresponding author
}

\begin{abstract}
This special issue of Renewable and Sustainable Energy Reviews is devoted to the research presented and discussed at the $10^{\text {th }}$ Conference on Sustainable Development of Energy, Water and Environment Systems (SDEWES) held from the $27^{\text {th }}$ September to the $2^{\text {nd }}$ October 2015 in Dubrovnik, Croatia. The contents are in keeping with the aims and scope of the journal which is to bring together under one roof the current advances in the ever broadening field of renewable and sustainable energy. However, Conferences on Sustainable Development of Energy, Water and Environment system, and associated dedicated special issues, have gathered a significant amount of knowledge in these fields and can give a deeper insight into the direct measurable impacts on sustainability. The articles published in this special issue, together with other SDEWES special issues create a synergy that review, discuss and examine energy resources and technologies (e.g. biomass, hydropower, solar, geothermal and wind), applications and services (e.g. buildings, industry, electricity and transport) and policy and the environment (e.g. economics, emissions, politics, energy planning, social aspects) within the framework of sustainable development, which is very timely considering the Paris Agreement on Climate Change in 2015. A total of 35 extended manuscripts were invited by the guest editors of this special issue for consideration for publication in Renewable and Sustainable Energy Reviews. After a vigorous review process by expert reviewers in their respective fields and overseen by the guest editors a total of 22 articles were accepted for publication.
\end{abstract}




\section{Keywords}

Renewable energy, sustainable development, biomass, hydropower, solar, geothermal, wind, buildings, industry, electricity, transport, policy, environment, emissions, economics, social aspects, politics, energy planning, climate change

\section{List of abbreviations}

$\mathrm{AD}=$ anaerobic digestion

$\mathrm{AHP}=$ analytic hierarchy process

$\mathrm{AHP}=$ analytic hierarchy process

$\mathrm{BEM}=$ Building Energy Modelling

$\mathrm{BIM}=$ Building Information Modelling

$\mathrm{BOD}=$ biological oxygen demand

$\mathrm{BRE}=$ Building Research Establishment

$\mathrm{CHP}=$ combined heat and power

$\mathrm{CO}_{2}=$ carbon dioxide

$\mathrm{COP}=$ Conference of the Parties

$\mathrm{CP}=$ Coefficient of Performance

EIA $=$ Environmental impact assessments

ENSC $=$ Nash-Sutcliffe model efficiency coefficient

ESI $=$ Energy Security Index

ETS $=$ emissions trading scheme

$\mathrm{EU}=$ European Union

$\mathrm{EV}=$ electric vehicle

$\mathrm{GHG}=$ greenhouse gas

$\mathrm{GSH}=$ ground source heat

HAWP $=$ high altitude wind power

LDMI $=$ Logarithmic Mean Divisia Index

LIES $=$ Locally Integrated Energy Sector

LQG $=$ linear quadratic Gaussian

MENA $=$ Middle East and North Africa

MILP $=$ mixed integer linear programming

ORC $=$ Organic Rankine Cycle

$\mathrm{PAD}=$ pressurised anaerobic digestionpps $=$ pervious paving systems

$\mathrm{PV}=$ photovoltaics

RES $=$ renewable energy sources

SDEWES = Sustainable Development of Energy, Water and Environment Systems

SWOT $=$ strengths weaknesses opportunities and threats 
$\mathrm{TEC}=$ thermo-ecological cost

$\mathrm{TRL}=$ technology readiness level

$\mathrm{UK}=$ United Kingdom

$\mathrm{UASB}=$ Upflow Anaerobic Sludge Blanket

$\mathrm{ZEB}=$ zero energy buildings

\subsection{Introduction}

The $10^{\text {th }}$ Conference on Sustainable Development of Energy, Water and Environment Systems (SDEWES) held in Dubrovnik, Croatia from the $27^{\text {th }}$ September to the $2^{\text {nd }}$ October 2015 was hot on the trail of the United Nations Climate Change Conference or COP 21 held in Paris where 195 world leaders met to consider the Paris Agreement on Climate Change, which aims to limit global warming by significantly decarbonising human activity in a three pronged approach that combines efficiency, self-sufficiency and renewable energy in order to preserve the planet and humanity [1]. The Paris Agreement recognises the urgent need for finance, technology and capacity-building by developed countries to enable developing countries to deploy renewable energy and thus guarantee sustainable energy. One of the key conclusions is that combating climate change and securing sustainable development requires a multi sectorial and interdisciplinary approach and actions. This is one of the cornerstones of the series of Conferences on Sustainable Development of Energy, Water and Environment Systems. At SDEWES scientists and engineers from all over the world gather to discuss various technology and research, society and policy, in an interdisciplinary setting to share and gain a deeper understanding of key sustainability challenges. The main dissemination tool of SDEWES conferences are the dedicated special issues which are published in some of the most prestigious international scientific journals, dealing with energy and sustainability. The last SDEWES conference, held in Dubrovnik 2015, had in total 541 contributions, with 22 of these, presented in this special issue of Renewable and Sustainable Energy Reviews, having an important role to play in mapping the pathways to local, regional and ultimately global decarbonisation by informing key decision makers from industry and government of the findings of cutting-edge research and the state-of-the-art of existing and novel technologies in the field. The guest editors have a diverse background, expertise and knowledge in the field of sustainable energy including biofuels [2], [3], [4], wind [5], [6], [7], [8], [9] solar photovoltaics [10], [11], [12], [13] electric vehicles (EV) [14], [15], [16], [17], [18] greenhouse gas (GHG) emissions [19], [20], [21], [22], [23], electricity markets [24], [25], [26], [27], energy storage [28], [29], [30], [31], [32][33] and climate change measures [34], [35], [36], [37]. As academics and researchers in the field of sustainable energy we should aim to analyse the complex interaction of technology in terms of environmental costs, energy costs, energy security and economic opportunity to fully decarbonise human activity and preserve the planet. This interaction has recently been referred to as the 'energy quadrilemma' [38], [39], [40], [41]. 
The aim of this editorial is to briefly review the knowledge learned in the 22 articles published in this SDEWES special issue that have can have direct and indirect impacts on sustainability considering the Paris Agreement. Since this special issue also covers some interesting aspects of the 'energy quadrilemma' an extensive literature review of previous SDEWES special issue articles have included to utilise all the generated knowledge, create linkage and to emphasise the integration and interdisciplinary aspects of the research. The key findings of the articles in this special issue dedicated to SDEWES are summarised under the following topics: i) renewable energy resources and technologies (e.g. biomass, hydropower, solar, geothermal and wind), ii) decarbonisation of buildings, industry, electricity and transport and iii) case studies, policy and the environment (e.g. economics, emissions, politics, energy planning, and social aspects).

\subsection{Renewable energy resources and technologies}

Renewable energy resources and technologies have a critical role to play in achieving our challenging energy and GHG emissions reduction targets. However, in order to appreciate the role that these resources and technologies can play the capabilities, costs and technology readiness levels (TRL) of these must be understood. From the beginning, one of the main research focuses of SDEWES conferences were renewable energy sources (RES) and their integration into different energy systems. Now, fourteen years after the first SDEWES conference, we can say that clean energy systems, based on renewable energy resources are both technically and economically viable [42]. As a result of this, future energy systems need to change and integrate cross-sectorally (e.g. electricity, heating/cooling, water management and transport) in order to satisfy the paradigm in which the demand is following variable supply, in comparison to today's system where supply is following the demand. Maybe the most interest among SDEWES contributions, through all these years, can be attributed to solar and wind energy. When it comes to wind energy research, contributions have went from purely technical and design solutions, like innovative approach to the analysis of diffuser augmented wind turbines [43] or linear quadratic Gaussian (LQG) controllers for fatigue loads reduction [44], to policy and integration problems, which were probably the most represented. Authors have analysed specifics of wind power plants integration into transmission networks [45], arbitrage potentials as a mean of increasing wind penetration [46] and long term off-shore wind potentials in comparison to national energy targets [47]. When it comes to solar energy, researchers have been focused on analysing policy measures and non-technical barriers for higher PV integration [48] and the influence of Feed in tariffs on PV cost and geographic distribution [49]. Integration of solar energy (both PV and solar thermal) has also been a very active topic among SDEWES contributors. The synergies between PV pump hydro energy storage in rural dry areas has been analysed [50], as well as the potential utilisation of low temperature heat through the Organic Rankin Cycle (ORC) for solar domestic applications [51]. 
The ORC was particularly interesting in the utilisation of geothermal energy as well. In [52] authors are analysing basic and dual-pressure ORC with the implementation done on a specific geothermal plant, as s case study. One of the prerequisite of geothermal energy utilization is the creation of quality geothermal maps, which was the focus of [53], where neural networks were used to determine potentials at three different depths. Beside electricity generation, geothermal energy was also investigated as low temperature heat source for district heating. In the case of Frederikshavn, geothermal heat, in combination with absorption heat pump paves the road to a $100 \%$ renewable city. A 100\% renewable energy systems were an often focus of SDEWES conferences contributions. In many cases these efforts and analysis went beyond city or regional scales and analysed whole countries (Ireland [54], Japan [55], Macedonia [56] and Denmark [57]). Some of the research presented at SDEWES conferences included work on establishing, developing and evaluating energy analysis tools. The importance of the transport sector and its integration in the overall energy system has been discussed and shown in previous studies [58] as has the possibility to utilise advanced modelling techniques such as agent based modelling [59] In [60] the difficulty in simulating nonautomotive (e.g. forklifts) and non-highway (e.g. inner-city buses) vehicles is reviewed and the tools available to undertake such simulations are outlined. The key finding is that non-automotive and offhighway drivetrain simulation may require bespoke models involving both commercial (e.g. AVL Cruise, AMESim, Dynacar etc.) and software such as MATLAB/Simulink. Biogas, another renewable energy resource, has the potential to decarbonise energy systems. Previously, policy support to overcome techno-economic barriers of biogas utilisation and effects of different biogas distribution strategies were investigated in [61]. Two potential sectors for biogas use are covered and the results show that relatively low subsidies give significant increases in cost-effective biogas utilisation levels, although for full technical potential to be exploited, high subsidies are still needed. In [62] the decarbonisation of a power utility portfolio as a function of RES and decarbonisation goals proposed a novel method of power generation portfolio optimization, along with appropriate criteria.

A further study [63] demonstrated the economic viability of larger biogas plants and the high impact transport has on these larger plants in rural areas. According to new research in [64] biogas can utilise the potential to decarbonise energy systems 'only if its lifecycle carbon dioxide $\left(\mathrm{CO}_{2}\right)$ footprint is lower than that of displaced conventional technologies, which is sometimes uncertain.' This research on biogas also noted that the typical life cycle $\mathrm{CO}_{2}$ footprint of biogas ranges from 50 to 450 $\mathrm{kgCO}_{2} / \mathrm{MWh}_{\mathrm{el}}$ based on an in-depth review of the published academic literature and found that pressurised anaerobic digestion (PAD) based biogas plants produce higher purity biomethane with a much lower direct $\mathrm{CO}_{2}$ footprint of $13 \mathrm{~kg} / \mathrm{MWh}_{\mathrm{f}}$ (where $\mathrm{f}$ means footprint of biomethane) based on a case study involving six plant configurations compared to conventional combined heat and power (CHP) systems with a direct $\mathrm{CO}_{2}$ footprint of $700 \mathrm{kgCO}_{2} / \mathrm{MWh}_{\mathrm{el}}$ (where el means footprint of electricity). Previously, the mathematical approach for improving the reliability of parameter 
calibration in modelling of anaerobic digestion (AD) processes has been investigated in [65], where the modified Nash-Sutcliffe model efficiency coefficient (ENSC) was used to assess the quality of simulations compared to observed data from the mesophilic mono-fermentation of grass silage. An alternative approach using an Upflow Anaerobic Sludge Blanket (UASB) reactor was investigated in [66] for the treatment of wastewater with biogas production. On a similar topic, [67] overviews feed control methodologies of (AD) processes for renewable energy production of biogas. The review concluded that although many sophisticated controllers exist most full-scale biogas plant operate using a closed-loop feed control, and that the most sophisticated controllers were found at anaerobic wastewater treatment plants, whereas the least sophisticated controllers were found at agricultural and industry based $\mathrm{AD}$ plants due to a conservative approach that avoided online instrumentation for process monitoring. An assessment of sustainability guidelines of the European Union (EU) RES Directive was given in [68] for the case of bio-refineries. An exergy analysis [69] was performed to evaluate the alternatives for microalgae oil extraction. In [70] third generation biofuel technologies such as algal-based biorefineries are proposed as a sustainable alternative to first generation foodbased biofuels due to 'the food-versus-fuel debate and indirect land-use change emissions'. However, there remains much debate on the techno-economic problems faced by biofuels produced from algalbased biorefineries, which is in part due to the different research methodologies employed in the published studies. This in-depth review article examined sixty-four environmental studies, forty economic analyses and twenty studies to provide a qualitative-basedassessment of algal-based biorefineries to establish a generic environmental techno-economic methodology to streamline LCA to reduce time-to-market for new sustainable technologies.

In [71], the first microgrid being developed in the Western Balkan region serves as pilot site for introduction and examination of microgrid concepts in non-EU conditions. A community microgrid and consumer demand response was used to utilise demand-supply matching in [72]. Adaptive controls using integrated mixed integer linear programming (MILP) were used in [73] to assess the flexibility benefits of microgrid systems and operational costs savings were demonstrated. [74] provides a systematic review of published research on the environmental and economic impacts of smart grids. This in-depth and detailed study highlighted the inconsistency in the methods used, the underlying assumptions and results, and recommended that 'there is a need to develop and test a framework for cost-benefit assessments' of smart grid systems. New novel technologies are also assessed in this SDEWES special issue. High altitude wind power (HAWP) is an attention-grabbing technology. So far, the physical concepts supporting the implementation were demonstrated in [75], which showed a theoretical feasibility of the Magnus' effect as a concept for harvesting high altitude winds. Also, the costs, size, and durability of energy storage systems for a HAWP application were investigated in [76]. A solution for construction using a variable-length tether was elaborated in [77], describing the shape, forces and vibrations of the tether. A techno-economic analysis of HAWP in 
Northern Ireland determined a total viable optimal land area of $5109.6 \mathrm{~km}^{2}$ with 'an average wind power density of $1998 \mathrm{~W} / \mathrm{m}^{2}$ over a 20 -year span, at a fixed altitude of $3000 \mathrm{~m}$ ' and calculated a preliminary budget cost of approximately $£ 1.75$ million for a $2 \mathrm{MW}$ pumping kite device [78].

\subsection{Decarbonisation of buildings, industry, electricity and transport}

The electrification and decentralisation of heating, cooling and other energy loads in buildings and industry is another piece of the puzzle on the roadmap to societal decarbonisation. There are many developments and activities on-going globally that are taking different technologies in isolation and in combination to reduce the energy and GHG emissions footprint of society. When it comes to heating and cooling, shifting towards nearly zero energy buildings (ZEB) require new low temperature solutions. As a main decentralised solution, capable of serious primary energy savings, heat pumps are identified. For example, in [79], opportunities for exploitation of open-loop groundwater heat pump are presented. Energy analysis of the system shows that ground-water heat pumps constitute an interesting option in areas with small housing density. In [80], results of an optimal design process were presented for a ground-source heat pump system including thermal modelling of the system and selection of optimal design parameters which affect the system performance and operational costs. In [81] combined ground source heat (GSH) pervious paving systems (pps) and rainwater harvesting is reviewed and unpublished data from the 'Hanson Ecohouse' on the Innovation Park at the Building Research Establishment (BRE) in Garston, Watford in the United Kingdom (UK) is described. The key findings of the work are that the Coefficient of Performance (CP) based on a literature review of such combined systems is viable and can reach the 2.875 which meets the EU RES Directive [82]. Small-scale laboratory testing indicated that a combined GSH pps rainwater harvesting system reduced the pollutants (i.e. 99\% for biological oxygen demand (BOD) and 95\% for ammonianitrogen); and not only does the combined system provide clean renewable energy it also provides flood mitigation.

Decarbonisation is based on the cross-sectoral integration of renewable energy as a substitute for fossil fuels, on one side and efficient usage of resources on the other. In that sense cogeneration and trigeneration plants present another valuable mean of utilising both RES and fossil fuels. Trigeneration systems and their thermo-ecological cost (TEC) for various fuels was investigated in [83]. A decision tool for trigeneration systems in buildings sector was demonstrated in [84] showing the optimisation of the plant lay-out, the sizes of the main components and their operation strategy for a hotel building. Similarly, in [85] micro-trigeneration for residential applications (i.e. heating, cooling and hot water production) are reviewed and tested on three multi-family houses in Palermo, Naples and Milan in Italy over a year using the transient simulation software tool TRANSYS 17 [86]. The results were then compared with a conventional standalone system and showed a reduced i) primary energy consumption (e.g. $4.3 \%$ in Palermo), ii) equivalent $\mathrm{CO}_{2}$ emissions (e.g. 10.6\% Milan) and iii) annual 
operating costs (e.g. 11.3\% Palermo). However, the pay-back period was only acceptable in Milan considering current economic incentives in Italy. Another technology that can reduce the energy use, costs and carbon footprint of buildings is shallow geothermal energy system. In [87] the use of geothermal energy in combination with an absorption heat pump was examined and shows promise for district heating application and reduction of fossil fuel consumption. A study of shallow geothermal energy systems in [88] summarised that the published research and compared the levels of deployment and regulatory requirements in six EU countries (i.e. Italy, Spain, Germany, the UK, France and Sweden). The correlation between deployment, research activity and the effectiveness and cohesiveness of EU regulations was also examined. Ironically, although Italy was one of the most active countries in terms of research, this did not translate into the regulatory requirements. Integrating different energy sources and sinks in systems is one way to decarbonise buildings, industry, electricity and transport. This can be implemented using different modelling approaches. In [89] a literature review of the state-of-the-art of Building Information Modelling (BIM) to Building Energy Modelling (BEM) for industrial facilities and a case study of adopting a BIM to BEM approach at two industrial facilities to enable more efficient life-cycle management is provided. In the conclusion the barriers and challenges to BIM adoption and the benefits of the BIM to BEM workflow in an industrial setting are identified. The utilisation of life cycle cost calculations has been discussed in previous research showing the need for its adoption and customisation [90] while the research conducted in [91] demonstrated a novel approach for building energy efficient automation, meaning the simulation and optimisation of energy consumption and better integration of energy systems on a building level. Another method to analyse energy optimisation and integration in thermodynamic systems and processes is the Pinch Analysis [92]. This method is widespread in process engineering and is usually utilised for the optimisation of industrial processes such as in [93], but its modifications can also be used in for example, the transport sector [94]. Here an extension of the Pinch Analysis is applied to 'industrial, residential, commercial, institutional and service energy systems' to maximise the incorporation and 'reuse of waste and low potential heat, including renewables to boost sustainability' in an approach called Locally Integrated Energy Sector (LIES) is overviewed in detail in [95].

\subsection{Case studies, policy and the environment}

Case studies on the success, challenges and impacts of renewable and sustainable energy projects are useful to inform society, industry and decision-makers on policy and environment plans on prioritising and implementing best practice in solving the 'energy quadrilemma.' In this SDEWES special issue a number of the articles identify some of the competing forces seen in the 'energy quadrilemma' using case studies. Previous studies have shown the possibility to assess the technical or economic potential for the utilization of certain technologies or energy sources in a given region, such as the potential for the utilisation of industrial waste heat in Croatia [96], the potential for the utilization concentrated solar power in Middle East and North Africa (MENA) countries [97] and photovoltaics (PV) in the 
Canary Islands [98]. In [99] the potential for locating solar plants in the Esfahan province, one of the main industrial centres in central Iran is presented considering environmental, geomorphological, location, climatic and various constraint parameters using an analytic hierarchy process (AHP). The case study determined that $3.12 \%$ (or $3,339 \mathrm{~km}^{2}$ ), $76.8 \%$ (or $82,189 \mathrm{~km}^{2}$ ) and $11.9 \%$ (or $12,735 \mathrm{~km}^{2}$ ) of the land area of the Esfahan province has excellent, good and valid surface potential to deploy solar plants. Brazil has been the focus of several previous studies such as the research conducted in [100] where the prospects for the utilisation of biofuels up to 2030 is investigated and [101] which deals with the possibility to utilize sugarcane biomass for power production. The objective of [102] was to qualitatively summarise the Brazilian electricity sector to 2030 considering uncertainties in energy usage, demand and development (e.g. smart grid, EVs, commercial and regulatory trends etc.) and consumer behaviour. The key finding is a series of guidelines to achieve the challenging 'Energy in Future City' scenario. The relation between the farming sector and energy has been discussed in previous research such as [103] where the potential for the utilisation of biogas was demonstrated and [104] where the use of agricultural biomass in CHP has been presented on a study for Serbia. In another case study [105] the effect of increases in electricity costs on 58 farming communities in north-eastern Spain are investigated and changes in the current tariff structure as well as increases in self-consumption are proposed to reduce energy costs and mitigate sector problems. The measurement of the success or failure of policies and technologies requires standardised metrics or indicators to allow a useful comparison by decision makers. In [106] a new energy security indicator with longterm sustainability is defined and tested on a sample of 28 EU Member States from 1990 to 2012. This indicator includes environmental and social aspects in the weighting of the index unlike other metrics previously used (e.g. Herfindahl-Hirschmann Index, Supply/Demand Index, Oil Vulnerability Index etc.). The study results indicated a positive trend overall in Energy Security Index (ESI) values, except in the case of former Eastern Bloc countries. Each of the main indicators have been studied in separate articles, such as energy intensity, with all the positive and negative aspects of using it [107]. Some research articles have analysed various parameters influencing energy development and have also defined a level of sustainable energy development, for example on a case study for Western Balkan countries [108]. Usually the analyses of various energy policy impacts are done for a specific energy policy measure and sector, such as industry [109], power sector [110], transport sector [111], buildings [112] etc. However, a study [113] used the Logarithmic Mean Divisia Index (LDMI) decomposition method to examine the effectiveness of sustainable development policy drivers in the energy sector in a cross-country comparison approach of three developed countries (i.e. UK, Portugal and Spain) and three developing countries (i.e. Brazil, China and India) and found that the LMDI decomposition method identifies the dominant factors in sustainable policy design. Case studies can also provide useful information to decision makers, industry and society on innovative technology deployment in terms of effectiveness and challenges. In terms of deploying new and innovative technology potential needs to be determined. In [114] the issue of waste palm cooking oil was analysed as one of the 
important quests towards sustainable development. The disposal was analysed through an environment friendly route and was utilised as an alternative for refined vegetable oil. In [115] biomethanol production with endemic chenopod as a substrate was investigated. This specific endemic chenopod displayed strong productivity and adeptness, while the special focus of the research was on the specific yields per hectare.

In [116] the carbon sequestration potential of different biomass-to-energy techniques for agricultural residues in five countries in the Mekong River basin in Southeast Asia is examined using a regression model. The analysis calculated that the conversion of agricultural residues to bioethanol, biogas and co-combustion sequestered approximately $98 \mathrm{TgCO}_{2}, 161 \mathrm{TgCO}_{2}$ and $488 \mathrm{TgCO}_{2}$, respectively thus mitigating the carbon footprint of agriculture. Environmental impact assessments (EIA) and studies are widely used to ensure and support sustainable development, which often involves competing considerations and the safeguard of protected areas. Macchia Lucchese or the Pineta di Levante near Viareggio in Northern Tuscany in Italy is one such protected area and in [117] the strengths, weaknesses, opportunities and threats of connecting three campsites, the coast and the Regional Park of Migliarino, San Rossore and Massaciuccoli by a diesel-powered train or an electric train are described. In [118] a simple, but interesting multicriteria analysis was used to measure eco-innovation. Afterwards this was applied to the transport system in order to prioritise various actions so further assessments of these actions could be made. In [119] an accent on sustainability of rural tourism in Spain was created. The assessment was made, acquiring qualitative data through personal interviews with experts and a strengths weaknesses opportunities and threats (SWOT) analysis to answer the question of theoretical framework of sustainable tourism.

The complex interactions of the energy-water nexus are explored in [120] by optimising the role of desalination, water storage and 'airspace' at a small hydro dam in Sydney, Australia to meet three objectives (i.e. meet the city's water needs, mitigate flooding and generate electricity while buffering any floods). the gap between water supply and demand planning in relation to social and economic strategies is addressed, since no comprehensive life-cycle approaches on modelling urban water balances were present in [121]. A system dynamics model and applied to the south-east Queensland region in Australia in [122] to analyse ongoing strategies as a response to prolonged droughts in Australia, primarily through the expansion of the desalination plants. The focus of the research was in the context of a decision of a large desalination plant that could be built in Sydney. As a result, a disconnection between the key factors (planning process, community engagement and political decision making) was identified and analysed.

A case study of major policy measures for biofuels in passenger car transport across fifteen EU Members States found that although a $\mathrm{CO}_{2}$ emission standard is important in reducing fuel 
consumption and $\mathrm{CO}_{2}$ emissions. It was found that this standard was alone not effective in the absence of accompanying policy measures (e.g. a $\mathrm{CO}_{2}$-based fuel tax) considering increasing car sizes and vehicle km driven [123]. In previous research [111] various fuel intensity and effects on energy demand of passenger cars in the EU-15 was analysed. Special focus in this research was on the rebound effect and its influence on energy conservation due to changes in car size and fuel intensity. The main conclusion was that the various energy efficiency policies will have a limited effect if some kind of fuel taxation is not introduced. The focus of [100] was on GHG reduction potential through the implementation of biofuels in the transport sector. Another objective was to investigate long term market potential of biofuels till 2030 for the three most important markets; USA, EU and Brazil.

In 2014 the EU agreed a climate and energy policy framework [124] for 2030 that set three key targets to 1) cut GHG emissions by at least $40 \%$ from 1990 levels, 2) reach a $27 \%$ share in renewable energy and 3) improve energy efficiency by at least $27 \%$. In [125] a thorough comparative analysis of untapped energy efficiency potentials in all 28 EU Member States indicates that despite the inadequacies in the database the goal of achieving a $27 \%$ improvement in energy efficiency by 2030 'appears to be quite feasible with high policy effort'. It is obvious that achieving these targets will require a cross sector efforts, primarily in the buildings, transport, industry and power sector. Numerous research have already been done sector wise. In [126] environmental taxation policy at the EU level was studied in order to measure its financial effects. In [127] energy efficiency improvements on the European building stock until 2050 was examined. Results have shown that the EU 2020 goals for primary energy savings could be met with a strong focus on $2 \%$ yearly efficiency improvements at useful energy level. In [128] the energy efficiency improvements in the EU building stock was also analysed, but in this case by extensive survey questioners. The main idea was to have a clearer vision on the current national frameworks. It is clear from the resaecrh in this special issue that overall EU targets will be a combination of cross sector efforts. In [129] informational efficiency of the EU Emissions Trading (ETS) Scheme as a major part of the future efforts in levering GHG emissions and increasing overall energy efficiency was examined.

\subsection{Discussion and conclusion}

Research is clearly flourishing in the field of sustainability and renewable energy. The field is multidisciplinary due to the nature of the issues involved. Sometimes this can become a challenge and limit the exchange of ideas, particularly between practitioners (e.g. scientists, engineers, architects, town planners, lawyers, doctors etc.), society and policy makers, as silos can inadvertently grow. For example, silos can inadvertently develop amongst practitioners as students. This is investigated from the perspective of training engineering students in [130]. The study also refers to a longitudinal study [131] that questions the success of engineering education to foster engineers with a 'sense of professional responsibility to the welfare of the public.' This question could, of course, be posed to all 
professions. Indeed, it could be further argued that social and environmental responsibility is learned at an early age from family, peers and the rest of society. However, those committed to the environment, reduced GHG emissions, renewable energy and eliminating energy poverty must keep positive. In [132] the focus is the challenges in engineering education, especially energy, in order to implement and amplify the role of multimedia in the learning process. In the work several issues are addressed from the basic skills and knowledge necessary for the students to the development of tools, methods or virtual libraries. In [133] it is argued that sustainability in engineering education needs to be addressed at meta-level using primarily a whole of system approach.

The research discussed and presented at SDEWES conferences shine a light on the interdisciplinary interactions, research and positive social conscious amongst researchers, society and policy makers. In conclusion, this SDEWES special issue edition of Renewable and Sustainable Energy Reviews gives just a small snapshot of the policies, technologies and environmental measures in place and proposed to decarbonise anthropogenic activities that demonstrate the growing social commitment and consciousness of society as a whole to preserve our beautiful planet.

\section{Acknowledgements}

The five guest editors of this special issue dedicated to SDEWES would like to thank the Editor-inChief, Lawrence Kazmerski and the administrative staff of Renewable and Sustainable Energy Reviews including Wendy Ye (Publishing Content Specialist - STM Journals), Janaki Bakthavachalam (Journal Manager), Katherine Eve (Executive Publisher) and Rosanna Diogini (Senior Publisher) for their support and invaluable work. We also gratefully acknowledge our reviewers' diligence, commitment and effort.

\section{References}

[1] UNFCCC. Report of the Conference of the Parties on its twenty-first session, held in Paris from 30 November to 13 December 2015. Addendum-Part Two Action Tak by Conf Parties 2015;1194:1-36.

[2] Smyth BM, Smyth H, Murphy JD. Determining the regional potential for a grass biomethane industry. Appl Energy 2011;88:2037-49. doi:10.1016/j.apenergy.2010.12.069.

[3] Smyth BM, Murphy JD, O'Brien CM. What is the energy balance of grass biomethane in Ireland and other temperate northern European climates? Renew Sustain Energy Rev 2009;13:2349-60. doi:10.1016/j.rser.2009.04.003.

[4] Smyth BM, Ó Gallachóir BP, Korres NE, Murphy JD. Can we meet targets for biofuels and renewable energy in transport given the constraints imposed by policy in agriculture and energy? J Clean Prod 2010;18:1671-85. doi:10.1016/j.jclepro.2010.06.027.

[5] Batas Bjelić I, Rajaković N, Ćosić B, Duić N. Increasing wind power penetration into the 
existing Serbian energy system. Energy 2013;57:30-7. doi:10.1016/j.energy.2013.03.043.

[6] Segurado R, Madeira JFA, Costa M, Duić N, Carvalho MG. Optimization of a wind powered desalination and pumped hydro storage system. Appl Energy 2016;177:487-99. doi:10.1016/j.apenergy.2016.05.125.

[7] Higgins P, Li K, Devlin J, Foley AM. The significance of interconnector counter-trading in a security constrained electricity market. Energy Policy 2015;87:110-24. doi:10.1016/j.enpol.2015.08.023.

[8] Yan J, Li K, Bai E-W, Deng J, Foley AM. Hybrid Probabilistic Wind Power Forecasting Using Temporally Local Gaussian Process. IEEE Trans Sustain Energy 2016;7:87-95. doi:10.1109/TSTE.2015.2472963.

[9] Higgins P, Foley A. The evolution of offshore wind power in the United Kingdom. Renew Sustain Energy Rev 2014;37:599-612. doi:10.1016/j.rser.2014.05.058.

[10] Novosel T, Ćosić B, Pukšec T, Krajačić G, Duić N, Mathiesen BV, et al. Integration of renewables and reverse osmosis desalination - Case study for the Jordanian energy system with a high share of wind and photovoltaics Energy 2015;92:270-8. doi:10.1016/j.energy.2015.06.057.

[11] Haas R, Lettner G, Auer H, Duic N. The looming revolution: How photovoltaics will change electricity markets in Europe fundamentally. Energy 2013;57:38-43. doi:10.1016/j.energy.2013.04.034.

[12] Markovska N, Krkoleva A, Taseska V, Borozan V, Pop-Jordanov J. Enabling an environment for solar and wind energy deployment in the Macedonian agricultural sector. J Renew Sustain Energy 2013;5:41804. doi:10.1063/1.4812996.

[13] Novosel T, Ćosić B, Krajačić G, Duić N, Pukšec T, Mohsen MS, et al. The influence of reverse osmosis desalination in a combination with pump storage on the penetration of wind and PV energy: A case study for Jordan. Energy 2014.

[14] Yang Z, Li K, Foley A. Computational scheduling methods for integrating plug-in electric vehicles with power systems: A review. Renew Sustain Energy Rev 2015;51:396-416. doi:10.1016/j.rser.2015.06.007.

[15] Foley A, Tyther B, Calnan P, Ó Gallachóir B. Impacts of Electric Vehicle charging under electricity market operations. Appl Energy 2013;101:93-102. doi:10.1016/j.apenergy.2012.06.052.

[16] YANG Z, LI K, NIU Q, XUE Y, FOLEY A. A self-learning TLBO based dynamic economic/environmental dispatch considering multiple plug-in electric vehicle loads. J Mod Power Syst Clean Energy 2014;2:298-307. doi:10.1007/s40565-014-0087-6.

[17] Prebeg P, Gasparovic G, Krajacic G, Duic N. Long-term energy planning of Croatian power system using multi-objective optimization with focus on renewable energy and integration of electric vehicles. Appl Energy 2016. doi:10.1016/j.apenergy.2016.03.086. 
[18] Pukšec T, Krajačić G, Lulić Z, Mathiesen BV, Duić N. Forecasting long-term energy demand of Croatian transport sector. Energy 2013;57:169-76. doi:10.1016/j.energy.2013.04.071.

[19] Dedinec A, Markovska N, Taseska V, Kanevce G, Bosevski T, Pop-Jordanov J. The potentional of renewable energy sources for greenhouse gases emissions reduction in Macedonia. Therm Sci 2012;16:717-28. doi:10.2298/TSCI120202128D.

[20] Smyth BM, Murphy JD. The indirect effects of biofuels and what to do about them: the case of grass biomethane and its impact on livestock. Biofuels, Bioprod Biorefining 2011;5:165-84. doi:10.1002/bbb.276.

[21] Smyth B, Crilly A, McDowell K. Water efficiency as a means of reducing carbon emissions in Northern Ireland (NI) water. J Water Supply Res Technol 2013;62:525. doi:10.2166/aqua.2013.061.

[22] Mikulčić H, Klemeš JJ, Vujanović M, Urbaniec K, Duić N. Reducing greenhouse gasses emissions by fostering the deployment of alternative raw materials and energy sources in the cleaner cement manufacturing process. J Clean Prod 2016;136:119-32. doi:10.1016/j.jclepro.2016.04.145.

[23] Pukšec T, Mathiesen BV, Novosel T, Duić N. Assessing the impact of energy saving measures on the future energy demand and related GHG (greenhouse gas) emission reduction of Croatia. Energy 2014.

[24] Foley AM, Ó Gallachóir BP, McKeogh EJ, Milborrow D, Leahy PG. Addressing the technical and market challenges to high wind power integration in Ireland. Renew Sustain Energy Rev 2013;19:692-703. doi:10.1016/j.rser.2012.11.039.

[25] Devlin J, Li K, Higgins P, Foley A. The importance of gas infrastructure in power systems with high wind power penetrations. Appl Energy 2016;167:294-304. doi:10.1016/j.apenergy.2015.10.150.

[26] Martin Almenta M, Morrow DJ, Best RJ, Fox B, Foley AM. Domestic fridge-freezer load aggregation to support ancillary services. Renew Energy 2016;87:954-64. doi:10.1016/j.renene.2015.08.033.

[27] Higgins P, Foley AM, Douglas R, Li K. Impact of offshore wind power forecast error in a carbon constraint electricity market. Energy 2014;76:187-97. doi:10.1016/j.energy.2014.06.037.

[28] Krajačić G, Duić N, Zmijarević Z, Mathiesen BV, Vučinić AA, da Graça Carvalho M. Planning for a $100 \%$ independent energy system based on smart energy storage for integration of renewables and CO2 emissions reduction. Appl Therm Eng 2011;31:2073-83. doi:10.1016/j.applthermaleng.2011.03.014.

[29] Ban M, Krajačić G, Grozdek M, Ćurko T, Duić N. The role of cool thermal energy storage (CTES) in the integration of renewable energy sources (RES) and peak load reduction. Energy 2012;48:108-17. doi:10.1016/j.energy.2012.06.070. 
[30] Higgins P, Foley A, Li K, Devlin J. System flexibility provision using short term grid scale storage. IET Gener Transm Distrib 2016;10:697-703. doi:10.1049/iet-gtd.2015.0460.

[31] Foley A, Díaz Lobera I. Impacts of compressed air energy storage plant on an electricity market with a large renewable energy portfolio. Energy 2013;57:85-94. doi:10.1016/j.energy.2013.04.031.

[32] Fitzgerald N, Foley AM, McKeogh E. Integrating wind power using intelligent electric water heating. Energy 2012;48:135-43. doi:10.1016/j.energy.2012.03.014.

[33] Krajačić G, Lončar D, Duić N, Zeljko M, Lacal Arántegui R, Loisel R, et al. Analysis of financial mechanisms in support to new pumped hydropower storage projects in Croatia. Appl Energy 2013;101:161-71. doi:10.1016/j.apenergy.2012.07.007.

[34] Heidrich O, Reckien D, Olazabal M, Foley A, Salvia M, de Gregorio Hurtado S, et al. National climate policies across Europe and their impacts on cities strategies. J Environ Manage 2016;168:36-45. doi:10.1016/j.jenvman.2015.11.043.

[35] Reckien D, Flacke J, Dawson RJ, Heidrich O, Olazabal M, Foley A, et al. Climate change response in Europe: what's the reality? Analysis of adaptation and mitigation plans from 200 urban areas in 11 countries. Clim Change 2014;122:331-40. doi:10.1007/s10584-013-0989-8.

[36] Dedinec A, Markovska N, Ristovski I, Velevski G, Gjorgjievska VT, Grncarovska TO, et al. Economic and environmental evaluation of climate change mitigation measures in the waste sector of developing countries. J Clean Prod 2015;88:234-41. doi:10.1016/j.jclepro.2014.05.048.

[37] Dedinec A, Markovska N, Taseska V, Duic N, Kanevce G. Assessment of climate change mitigation potential of the Macedonian transport sector. Energy 2013;57:177-87. doi:10.1016/j.energy.2013.05.011.

[38] Olabi AG. Energy quadrilemma and the future of renewable energy. Energy 2016;108:1-6. doi:10.1016/j.energy.2016.07.145.

[39] Lund H, Østergaard PA, Stadler I. Towards 100\% renewable energy systems. Appl Energy 2011;88:419-21. doi:10.1016/j.apenergy.2010.10.013.

[40] Connolly D, Lund H, Mathiesen BV. Smart Energy Europe: The technical and economic impact of one potential 100\% renewable energy scenario for the European Union. Renew Sustain Energy Rev 2016;60:1634-53. doi:10.1016/j.rser.2016.02.025.

[41] Krajačić G, Duić N, Vujanović M, Kılkış Ş, Rosen MA, Al-Nimr MA. Sustainable development of energy, water and environment systems for future energy technologies and concepts. Energy Convers Manag 2016;125:1-14. doi:10.1016/j.enconman.2016.08.050.

[42] Duić N. Is the success of clean energy guaranteed? Clean Technol Environ Policy 2015;17:2093-100. doi:10.1007/s10098-015-0969-y.

[43] Tavares Dias do Rio Vaz DA, Amarante Mesquita AL, Pinheiro Vaz JR, Cavalcante Blanco CJ, Pinho JT. An extension of the Blade Element Momentum method applied to Diffuser 
Augmented Wind Turbines. Energy Convers Manag 2014;87:1116-23. doi:10.1016/j.enconman.2014.03.064.

[44] Camblong H, Nourdine S, Vechiu I, Tapia G. Control of wind turbines for fatigue loads reduction and contribution to the grid primary frequency regulation. Energy 2012;48:284-91. doi:10.1016/j.energy.2012.05.035.

[45] Capuder T, Pandžić H, Kuzle I, Škrlec D. Specifics of integration of wind power plants into the Croatian transmission network. Appl Energy 2013;101:142-50. doi:10.1016/j.apenergy.2012.05.002.

[46] Andresen GB, Rodriguez RA, Becker S, Greiner M. The potential for arbitrage of wind and solar surplus power in Denmark. Energy 2014;76:49-58. doi:10.1016/j.energy.2014.03.033.

[47] Hong L, Möller B. Feasibility study of China's offshore wind target by 2020. Energy 2012;48:268-77. doi:10.1016/j.energy.2012.03.016.

[48] Bhandari R. Electrification using solar photovoltaic systems in Nepal. Appl Energy 2011;88:458-65. doi:10.1016/j.apenergy.2009.11.029.

[49] Antonelli M, Desideri U. Do feed-in tariffs drive PV cost or viceversa? Appl Energy 2014;135:721-9. doi:10.1016/j.apenergy.2014.06.059.

[50] Stoppato A, Cavazzini G, Ardizzon G, Rossetti A. A PSO (particle swarm optimization)-based model for the optimal management of a small PV(Photovoltaic)-pump hydro energy storage in a rural dry area. Energy 2014;76:168-74. doi:10.1016/j.energy.2014.06.004.

[51] Barbazza L, Pierobon L, Mirandola A, Haglind F. Optimal design of compact organic Rankine cycle units for domestic solar applications. Therm Sci 2014;18:811-22. doi:10.2298/TSCI1403811B.

[52] Guzović Z, Rašković P, Blatarić Z. The comparision of a basic and a dual-pressure ORC (Organic Rankine Cycle): Geothermal Power Plant Velika Ciglena case study. Energy 2014;76:175-86. doi:10.1016/j.energy.2014.06.005.

[53] Kalogirou SA, Florides GA, Pouloupatis PD, Panayides I, Joseph-Stylianou J, Zomeni Z. Artificial neural networks for the generation of geothermal maps of ground temperature at various depths by considering land configuration. Energy 2012;48:233-40. doi:10.1016/j.energy.2012.06.045.

[54] Connolly D, Lund H, Mathiesen BV, Leahy M. The first step towards a $100 \%$ renewable energy-system for Ireland. Appl Energy 2011;88:502-7. doi:10.1016/j.apenergy.2010.03.006.

[55] Morel J, Obara S, Morizane Y. Operation Strategy for a Power Grid Supplied by 100\% Renewable Energy at a Cold Region in Japan. J Sustain Dev Energy, Water Environ Syst 2014;2:270-83. doi:10.13044/j.sdewes.2014.02.0022.

[56] Ćosić B, Krajačić G, Duić N. A 100\% renewable energy system in the year 2050: The case of Macedonia. Energy 2012;48:80-7. doi:10.1016/j.energy.2012.06.078.

[57] Lund H, Mathiesen BV. Energy system analysis of 100\% renewable energy systems-The case 
of Denmark in years 2030 and 2050. Energy 2009;34:524-31. doi:10.1016/j.energy.2008.04.003.

[58] Mathiesen BV, Duić N, Stadler I, Rizzo G, Guzović Z. The interaction between intermittent renewable energy and the electricity, heating and transport sectors. Energy 2012;48:2-4. doi:10.1016/j.energy.2012.10.001.

[59] Novosel T, Perković L, Ban M, Keko H, Pukšec T, Krajačić G, et al. Agent based modelling and energy planning - Utilization of MATSim for transport energy demand modelling. Energy 2015;92:466-75. doi:10.1016/j.energy.2015.05.091.

[60] Briggs I, Murtagh M, Kee R, McCulloug G, Douglas R. Sustainable non-automotive vehicles: The simulation challenges. Renew Sustain Energy Rev 2016. doi:10.1016/j.rser.2016.02.018.

[61] Börjesson M, Ahlgren EO. Cost-effective biogas utilisation - A modelling assessment of gas infrastructural options in a regional energy system. Energy 2012;48:212-26. doi:10.1016/j.energy.2012.06.058.

[62] Kazagic A, Merzic A, Redzic E, Music M. Power utility generation portfolio optimization as function of specific RES and decarbonisation targets - EPBiH case study. Appl Energy 2014;135:694-703. doi:10.1016/j.apenergy.2014.09.001.

[63] Novosel T, Pukšec T, Duić N. Economic viability of centralized biogas plants: A case study for Croatia. Chem Eng Trans 2014;42:85-90. doi:10.3303/CET1442015.

[64] Budzianowski WM, Postawa K. Renewable energy from biogas with reduced carbon dioxide footprint: Implications of applying different plant configurations and operating pressures. Renew Sustain Energy Rev 2016. doi:10.1016/j.rser.2016.05.076.

[65] Koch K, Gehring T, Lubken M. Mathematical approach for improving the reliability of parameter calibration in modeling of anaerobic digestion processes. Stroj Časopis Za ... 2013;55:7-16.

[66] Nadais H, Barbosa M, Capela I, Arroja L, Ramos CG, Grilo A, et al. Enhancing wastewater degradation and biogas production by intermittent operation of UASB reactors. Energy 2011;36:2164-8. doi:10.1016/j.energy.2010.03.007.

[67] Gaida D, Wolf C, Bongards M. Feed control of anaerobic digestion processes for renewable energy production: A review. Renew Sustain Energy Rev 2016. doi:10.1016/j.rser.2016.06.096.

[68] Maes D, Van Dael M, Vanheusden B, Goovaerts L, Reumerman P, Márquez Luzardo N, et al. Assessment of the sustainability guidelines of EU Renewable Energy Directive: the case of biorefineries. J Clean Prod 2015;88:61-70. doi:10.1016/j.jclepro.2014.04.051.

[69] Peralta-Ruiz Y, González-Delgado A-D, Kafarov V. Evaluation of alternatives for microalgae oil extraction based on exergy analysis. Appl Energy 2013;101:226-36. doi:10.1016/j.apenergy.2012.06.065.

[70] Thomassen G, Van Dael M, Lemmens B, Van Passel S. A review of the sustainability of algal- 
based biorefineries: Towards an integrated assessment framework. Renew Sustain Energy Rev 2016. doi:10.1016/j.rser.2016.02.015.

[71] Krkoleva A, Taseska V, Markovska N, Taleski R, Borozan V. Microgrids: The agria test location. Therm Sci 2010;14:747-58. doi:10.2298/TSCI1003747K.

[72] Ravindra K, Iyer PP. Decentralized demand-supply matching using community microgrids and consumer demand response: A scenario analysis. Energy 2014;76:32-41. doi:10.1016/j.energy.2014.02.043.

[73] Holjevac N, Capuder T, Kuzle I. Adaptive control for evaluation of flexibility benefits in microgrid systems. Energy 2015;92:487-504. doi:10.1016/j.energy.2015.04.031.

[74] Moretti M, Djomo SN, Azadi H, May K, De Vos K, Van Passel S, et al. A systematic review of environmental and economic impacts of smart grids. Renew Sustain Energy Rev 2016. doi:10.1016/j.rser.2016.03.039.

[75] Perković L, Silva P, Ban M, Kranjčević N, Duić N. Harvesting high altitude wind energy for power production: The concept based on Magnus' effect. Appl Energy 2013;101:151-60. doi:10.1016/j.apenergy.2012.06.061.

[76] Pavković D, Hoić M, Deur J, Petrić J. Energy storage systems sizing study for a high-altitude wind energy application. Energy 2014;76:91-103. doi:10.1016/j.energy.2014.04.001.

[77] Milutinović M, Kranjčević N, Deur J. Multi-mass dynamic model of a variable-length tether used in a high altitude wind energy system. Energy Convers Manag 2014;87:1141-50. doi:10.1016/j.enconman.2014.04.013.

[78] Lunney E, Ban M, Duic N, Foley A. A state-of-the-art review and feasibility analysis of high altitude wind power in Northern Ireland. Renew Sustain Energy Rev 2016. doi:10.1016/j.rser.2016.08.014.

[79] Baccino G, Lo R, Taddia G, Verda V. Energy and environmental analysis of an open-loop ground-water heat pump system in an urban area. Therm Sci 2010;14:693-706. doi:10.2298/TSCI1003693B.

[80] Desmedt J, Van Bael J. Efficiency Investigation and Energy Saving of Vertical Ground Source Heat Pump. Strojarstvo 2010;52:405-9.

[81] Charlesworth SM, Faraj-Llyod AS, Coupe SJ. Renewable energy combined with sustainable drainage: Ground source heat and pervious paving. Renew Sustain Energy Rev 2016. doi:10.1016/j.rser.2016.02.019.

[82] European Parliament. Directive 2009/28/EC of the European Parliament and of the Council of 23 April 2009. Off J Eur Union 2009;140:16-62. doi:10.3000/17252555.L_2009.140.eng.

[83] Usón S, Kostowski WJ, Stanek W, Gazda W. Thermoecological cost of electricity, heat and cold generated in a trigeneration module fuelled with selected fossil and renewable fuels. Energy 2015;92:308-19. doi:10.1016/j.energy.2015.05.020.

[84] Piacentino A, Gallea R, Cardona F, Lo Brano V, Ciulla G, Catrini P. Optimization of 
trigeneration systems by Mathematical Programming: Influence of plant scheme and boundary conditions. Energy Convers Manag 2015;104:100-14. doi:10.1016/j.enconman.2015.03.082.

[85] Sibilio S, Rosato A, Ciampi G, Scorpio M, Akisawa A. Building-integrated trigeneration system: Energy, environmental and economic dynamic performance assessment for Italian residential applications. Renew Sustain Energy Rev 2016. doi:10.1016/j.rser.2016.02.011.

[86] TRNSYS. User Manual: TRNSYS 17 a TRaN sient SYstem Simulation program. TRNSYS Libr Vol 4 Math Ref Sol Energy Lab Univ Wisconsin-Madison, USA 2009;3:1-486.

[87] Østergaard PA, Lund H. A renewable energy system in Frederikshavn using low-temperature geothermal energy for district heating. Appl Energy 2011;88:479-87. doi:10.1016/j.apenergy.2010.03.018.

[88] Somogyi V, Sebestyén V, Nagy G. Scientific achievements and regulation of shallow geothermal systems in six European countries - A review. Renew Sustain Energy Rev 2016. doi:10.1016/j.rser.2016.02.014.

[89] Gourlis G, Kovacic I. Building Information Modelling for analysis of energy efficient industrial buildings - A case study. Renew Sustain Energy Rev 2016. doi:10.1016/j.rser.2016.02.009.

[90] Kovacic I, Zoller V. Building life cycle optimization tools for early design phases. Energy 2015;92:409-19. doi:10.1016/j.energy.2015.03.027.

[91] Marinakis V, Doukas H, Karakosta C, Psarras J. An integrated system for buildings' energyefficient automation: Application in the tertiary sector. Appl Energy 2013;101:6-14. doi:10.1016/j.apenergy.2012.05.032.

[92] Klemeš JJ, Kravanja Z. Forty years of Heat Integration: Pinch Analysis (PA) and Mathematical Programming (MP). Curr Opin Chem Eng 2013;2:461-74. doi:10.1016/j.coche.2013.10.003.

[93] Rašković P, Stoiljković S. Pinch design method in the case of a limited number of process streams. Energy 2009;34:593-612. doi:10.1016/j.energy.2008.04.004.

[94] Walmsley MRW, Walmsley TG, Atkins MJ, Kamp PJJ, Neale JR, Chand A. Carbon Emissions Pinch Analysis for emissions reductions in the New Zealand transport sector through to 2050. Energy 2015;92:569-76. doi:10.1016/j.energy.2015.04.069.

[95] Liew PY, Theo WL, Wan Alwi SR, Lim JS, Abdul Manan Z, Klemeš JJ, et al. Total Site Heat Integration planning and design for industrial, urban and renewable systems. Renew Sustain Energy Rev 2016. doi:10.1016/j.rser.2016.05.086.

[96] Biscan D, Filipan V. Potential of waste heat in Croatian industrial sector. Therm Sci 2012;16:747-58. doi:10.2298/TSCI120124123B.

[97] Moser M, Trieb F, Fichter T. Potential of Concentrating Solar Power Plants for the Combined Production of Water and Electricity in MENA Countries. J Sustain Dev Energy, Water Environ Syst 2013;1:122-40. doi:10.13044/j.sdewes.2013.01.0009.

[98] Schallenberg-Rodriguez J. Photovoltaic Techno-Economical Potential on Roofs in the Canary 
Islands. J Sustain Dev Energy, Water Environ Syst 2014;2:68-87. doi:10.13044/j.sdewes.2014.02.0007.

[99] Zoghi M, Houshang Ehsani A, Sadat M, javad Amiri M, Karimi S. Optimization solar site selection by fuzzy logic model and weighted linear combination method in arid and semi-arid region: A case study Isfahan-IRAN. Renew Sustain Energy Rev 2015. doi:10.1016/j.rser.2015.07.014.

[100] Ajanovic A, Haas R. On the future prospects and limits of biofuels in Brazil, the US and EU. Appl Energy 2014;135:730-7. doi:10.1016/j.apenergy.2014.07.001.

[101] Khatiwada D, Seabra J, Silveira S, Walter A. Power generation from sugarcane biomass - A complementary option to hydroelectricity in Nepal and Brazil. Energy 2012;48:241-54. doi:10.1016/j.energy.2012.03.015.

[102] Dantas G de A, de Castro NJ, Brandão R, Rosental R, Lafranque A. Prospects for the Brazilian electricity sector in the 2030s: Scenarios and guidelines for its transformation. Renew Sustain Energy Rev 2016. doi:10.1016/j.rser.2016.08.003.

[103] Puksec T, Duic N. Biogas Potential in Croatian Farming Sector. Strojarstvo 2010;52:441-8.

[104] Turanjanin V, Djurovic D, Dakic D, Eric A, Repic B. Development of the boiler for combustion of agricultural biomass by products. Therm Sci 2010;14:707-14. doi:10.2298/TSCI091113001T.

[105] Langarita R, Sánchez Chóliz J, Sarasa C, Duarte R, Jiménez S. Electricity costs in irrigated agriculture: A case study for an irrigation scheme in Spain. Renew Sustain Energy Rev 2016. doi:10.1016/j.rser.2016.05.075.

[106] Radovanović M, Filipović S, Pavlović D. Energy security measurement - A sustainable approach. Renew Sustain Energy Rev 2016. doi:10.1016/j.rser.2016.02.010.

[107] Filipović S, Verbič M, Radovanović M. Determinants of energy intensity in the European Union: A panel data analysis. Energy 2015;92:547-55. doi:10.1016/j.energy.2015.07.011.

[108] Golušin M, Munitlak Ivanović O, Redžepagić S. Transition from traditional to sustainable energy development in the region of Western Balkans - Current level and requirements. Appl Energy 2013;101:182-91. doi:10.1016/j.apenergy.2012.06.008.

[109] Danon G, Furtula M, Mandić M. Possibilities of implementation of CHP (combined heat and power) in the wood industry in Serbia. Energy 2012;48:169-76. doi:10.1016/j.energy.2012.02.073.

[110] Waite M, Modi V. Potential for increased wind-generated electricity utilization using heat pumps in urban areas. Appl Energy 2014;135:634-42. doi:10.1016/j.apenergy.2014.04.059.

[111] Ajanovic A, Schipper L, Haas R. The impact of more efficient but larger new passenger cars on energy consumption in EU-15 countries. Energy 2012;48:346-55. doi:10.1016/j.energy.2012.05.039.

[112] Pukšec T, Vad Mathiesen B, Duić N. Potentials for energy savings and long term energy 
demand of Croatian households sector. Appl Energy 2013;101:15-25. doi:10.1016/j.apenergy.2012.04.023.

[113] Lima F, Nunes ML, Cunha J, Lucena AFP. Driving forces for aggregate energy consumption: A cross-country approach. Renew Sustain Energy Rev 2016. doi:10.1016/j.rser.2016.08.009.

[114] Tan KT, Lee KT, Mohamed AR. Potential of waste palm cooking oil for catalyst-free biodiesel production. Energy 2011;36:2085-8. doi:10.1016/j.energy.2010.05.003.

[115] Yang B-Y, Cheng M-H, Ko C-H, Wang Y-N, Chen W-H, Hwang W-S, et al. Potential bioethanol production from Taiwanese chenopods (Chenopodium formosanum). Energy 2014;76:59-65. doi:10.1016/j.energy.2014.03.046.

[116] Ko C-H, Chaiprapat S, Kim L-H, Hadi P, Hsu S-C, Leu S-Y. Carbon sequestration potential via energy harvesting from agricultural biomass residues in Mekong River basin, Southeast Asia. Renew Sustain Energy Rev 2016. doi:10.1016/j.rser.2016.03.040.

[117] Del Moretto D, Colla V, Branca TA. Sustainable mobility for campsites: The case of Macchia Lucchese. Renew Sustain Energy Rev 2016. doi:10.1016/j.rser.2016.02.012.

[118] Scarpellini S, Valero A, Llera E, Aranda A. Multicriteria analysis for the assessment of energy innovations in the transport sector. Energy 2013;57:160-8. doi:10.1016/j.energy.2012.12.004.

[119] Sanagustín Fons MV, Fierro JAM, Patiño MG y. Rural tourism: A sustainable alternative. Appl Energy 2011;88:551-7. doi:10.1016/j.apenergy.2010.08.031.

[120] Sahin O, Stewart RA, Giurco D, Porter MG. Renewable hydropower generation as a co-benefit of balanced urban water portfolio management and flood risk mitigation. Renew Sustain Energy Rev 2016. doi:10.1016/j.rser.2016.01.126.

[121] Sahin O, Stewart RA, Porter MG. Water security through scarcity pricing and reverse osmosis: a system dynamics approach. J Clean Prod 2015;88:160-71. doi:10.1016/j.jclepro.2014.05.009.

[122] Giurco DP, Turner A, Fane S, White SB. Desalination for Urban Water : Changing Perceptions and Future Scenarios in Australia. Chem Eng Trans 2014;42:13-8. doi:10.3303/CET1442003.

[123] Ajanovic A, Haas R. The impact of energy policies in scenarios on GHG emission reduction in passenger car mobility in the EU-15. Renew Sustain Energy Rev 2016. doi:10.1016/j.rser.2016.02.013.

[124] European Commision. Communication from the Commission to the European Parliament, the Council, the European economic and social Committee and the Committee of the Regions - A policy framework for climate and energy in the period from 2020 to 2030. Eur Comm 2014:Brussels. doi:10.1007/s13398-014-0173-7.2.

[125] Knoop K, Lechtenböhmer S. The potential for energy efficiency in the EU Member States - A comparison of studies. Renew Sustain Energy Rev 2016. doi:10.1016/j.rser.2016.05.090.

[126] Filipović S, Golušin M. Environmental taxation policy in the EU - new methodology approach. J Clean Prod 2015;88:308-17. doi:10.1016/j.jclepro.2014.03.002.

[127] Ó Broin E, Mata É, Göransson A, Johnsson F. The effect of improved efficiency on energy 
savings in EU-27 buildings. Energy 2013;57:134-48. doi:10.1016/j.energy.2013.01.016.

[128] Annunziata E, Frey M, Rizzi F. Towards nearly zero-energy buildings: The state-of-art of national regulations in Europe. Energy 2013;57:125-33. doi:10.1016/j.energy.2012.11.049.

[129] Goers S. Testing Informational Efficiency in the EU ETS. J Sustain Dev Energy, Water Environ Syst 2014;2:319-30. doi:10.13044/j.sdewes.2014.02.0026.

[130] Mulder KF. Strategic competences for concrete action towards sustainability: An oxymoron? Engineering education for a sustainable future. Renew Sustain Energy Rev 2016. doi:10.1016/j.rser.2016.03.038.

[131] Cech EA. Culture of Disengagement in Engineering Education? Sci Technol Human Values 2014;39:42-72. doi:10.1177/0162243913504305.

[132] Klemeš JJ, Kravanja Z, Varbanov PS, Lam HL. Advanced multimedia engineering education in energy, process integration and optimisation. Appl Energy 2013;101:33-40. doi:10.1016/j.apenergy.2012.01.039.

[133] Mulder K, Desha C, Hargroves K. Sustainable Development as a Meta-Context for Engineering Education. J Sustain Dev Energy, Water Environ Syst 2013;1:304-10. doi:10.13044/j.sdewes.2013.01.0023. 